\title{
THE EFFECTS OF EARLY WORK EXPERIENCE ON YOUNG WOMEN'S LABOR FORCE ATTACHMENT
}

\author{
Sigal Alon \\ Debra Donahue \\ Marta Tienda
}

Office of Population Research

Working Paper No. 2000-04

Papers published in the OPR Working Paper Series reflect the views of individual authors. They may be cited in other publications, but are intended to be work-in-progress. Comments are welcome. Additional copies are available by writing to the Office of Population Research Working Paper Series, Princeton University, Wallace Hall, Second Floor, Princeton, NJ 08544. Fax: (609) 258-1039. Or on the web, http://opr.princeton.edu/ 


\title{
The Effects of Early Work Experience on Young Women's Labor Force Attachment*
}

\author{
Sigal Alon, Princeton University \\ Debra Donahoe, Princeton University \\ Marta Tienda, Princeton University
}

\section{Abstract}

In this article, we examine women's labor force experience during the early life course in order to assess the conditions conducive to the establishment of stable labor force careers. To represent the complexity of women's work trajectories during young adulthood, we develop a conceptual framework that depicts a broad range of work activity profiles. Empirical results obtained using the NLSY show that three aspects of early experience influence mature women's labor force attachment, namely the amount of experience accumulated; the timing of work experience; and the volatility of that experience. Above and beyond these experience measures, we also find that background factors influence adult women's attachment to the market. The conclusion discusses the policy implications of these results.

One of the most striking changes in the social landscape over the past several decades is the rapid rise in female labor force participation. This secular trend is driven simultaneously by an increase in the proportion of women working at any given point in time and a decrease in the propensity of working women to withdraw from the labor force when they become mothers. Not only are women now more likely to obtain employment then in the past, but they are also more likely to extend the length of their work spells. To wit, the yearly female labor force turnover rate,

* This research was supported by grants from the National Science Foundation (SBER \#9423230), NICHD (ST32HD07163-20), the MacArthur Foundation Network on Successful Development among Youth Reared in High Risk Settings, and the W.T. Grant Foundation to the Office of Population Research, Princeton University. Direct all correspondence to Sigal Alon, Office of Population Research, Wallace Hall, Princeton University, Princeton, NJ, 08540. E-mail: salon@princeton.edu. 


\section{6 / Social Forces 79:3, March 2001}

an indicator of annual labor force attachment that depict the extent to which the composition of the labor force turns over, decreased from 33\% in 1962 to $9 \%$ in 1994 (Blau et al. 1998, p. 84). Nevertheless, labor force instability remains a defining feature of women's work and it is unclear how the dynamism that characterizes women's early careers increases women's attachment to the world of work.

Although labor force participation rates are up and turnover rates are down, women's employment histories remain more complex and diverse than men's (Hseuh \& Tienda 1996; Moen \& Smith 1986). Traditionally the providers of nonmarket labor within the family, women have retained primary responsibility for the domestic arena even as their labor market involvement has increased. For example, women spend more hours on household chores and childcare (Blair \& Lichter 1991; Robinson 1988) and miss more days of work due to children's illnesses than do their husbands (Baruch et al. 1987). Women also tend to work closer to home, are more likely to work at home, and are more likely to be "tied" movers than men (Rosenfeld 1996). Despite women's rising commitment to the work force, it remains socially acceptable for women to choose endeavors other than work as their primary activity. Whether the context and conditions of female employment result from free or constrained choices, women's average attachment to the labor market, usually based on amount of time spent at work, remains weaker than men's (Hakim 1991; Light \& Ureta 1995; Wenk \& Rosenfeld 1992).

Recent research has highlighted the importance of employment instability in generating income inequality (Gottschalk \& Moffitt 1994; Hsueh \& Tienda 1995), sex differences in earnings (Elliott \& Parcel 1996; Gwartney-Gibbs 1988; Hill and O'Neill 1992) and the establishment of stable careers (Klerman and Karoly, 1995; Topel and Ward, 1992). Nonetheless, relatively few analysts have focused on the measurement of women's labor force instability, and even fewer have sought to relate early experiences with women's rising commitment to the market. Although links between early labor market experiences and subsequent adult outcomes have been scrutinized extensively for young men (Ahituv, Tienda \& Hotz 1997; Becker \& Hills 1980, 1983; Keane \& Wolpin 1997; Rich 1996; Ruhm 1995; Topel \& Ward 1992), there is no consensus about their impact (Donahoe \& Tienda 1999). Accordingly, in this article we examine labor force instability during the early life course in order to assess the conditions conducive to the establishment of stable labor force careers.

Our analyses contribute to the broader debate about whether and how much early labor force experiences influence subsequent labor force outcomes. Within this debate, we make several important refinements. First, we shift the focus from young men to young women. With few exceptions, most studies that attempt to establish links between early work experiences and subsequent adult outcomes focus on men (e.g., Hotz et al., 1999; Meyer \& Wise, 1982; Topel \& Ward, 1992; for a recent exception, see Chaplin \& Hannaway 1996). There are compelling 
reasons why the influence of early work experiences on adult market outcomes would differ by sex. The most obvious of these is the timing and influence of family responsibilities on women's work and school options (Ahituv et.al. 1998).

Second, we broaden the outcome of interest from unemployment (or, the probability of employment at a given age) to the establishment of stable work careers. Instead of focusing only on the effects of early labor force experience on specific outcomes at a single point in time, we emphasize the more substantively interesting issue of stability or continuity of labor force experience in adulthood, which we denote as attachment to the market. For this we develop a conceptual framework that addresses the complexity of diverse work trajectories during adolescence and early adulthood.

Third, we consider not only the quantity of early labor force experience, but its timing and volatility as well. To this end, we examine how the accumulation of work experience - that is, whether it is acquired continuously or discontinuously - influences adult labor market attachment. Because the way work experience is acquired depends partly on women's educational investments, especially time spent enrolled in higher education, we also compare how early work experience affects adult market attachment for college and high-school educated women.

Results show that all three aspects of early experience influence mature women's market attachment, namely the amount of experience accumulated; the timing of work experience; and the volatility of that experience. Above and beyond these experience measures, we also find that background factors influence adult women's attachment to the market.

The remainder of this article proceeds as follows. After a brief discussion of prior research, we describe the data and operational measures used to portray young women's early work experience. Subsequently, we characterize the emergence of stable work careers and describe the stability of employment between ages 16 and 28. Following a discussion of the conceptual framework representing labor force attachment, we assess whether and what types of early work experiences predict women's labor force attachment at ages $25-28$, when the majority of women have completed schooling and/or assumed other adult roles. The concluding section discusses the implications of key findings and identifies directions for future research.

\section{Background and Analytic Framework}

Among the numerous questions addressed by analysts of youth employment, two are especially prominent: (1) what is the magnitude of youth unemployment, both generally and among specific demographic groups (Clark \& Summers 1982; Stephenson 1982); and (2) what are the short- and long-term consequences of early labor market behavior on later employment prospects and wages (Ellwood 1982; Becker \& Hills 1980, 1983; Hotz et al. 1999; Meyer \& Wise 1982; Keane \& Wolpin 


\section{8 / Social Forces 79:3, March 2001}

1997; Topel \& Ward 1992). There are several theoretical reasons why early experience should influence later work status. Socialization theory postulates that early labor force experience gives young people a taste for working roles and shapes their aspirations for future social and economic achievement (Coleman 1984; Mortimer \& Finch 1992). Human capital theory stresses the benefits of work experience and job-specific training for creating labor market skills that increase future productivity. Both perspectives concur that early periods of non-work represent lost opportunities to acquire valuable labor force experience. For men there is ample evidence that labor market stratification begins early in the life course (Ahituv et al. 1997, Entwisle et al. 2000) and that adolescent employment enhances some labor market outcomes among young adults (Carr et al. 1996; Chaplin \& Hannaway 1996; Hotz et al. 1999; Ruhm 1995). However, there remains some dispute as to whether the benefits of working while enrolled in school outweigh the returns to attending school exclusively (Hotz et al. 1999).

Early labor force experience allegedly generates favorable market outcomes in subsequent years, but not all work episodes may produce equally valuable human capital. This is the crux of the debate about the benefits of high school employment - generally low-wage work with little possibility of advancement - for subsequent employment and wages (Mortimer \& Finch 1992; Steinberg et al. 1981). Work experience accumulated after school completion may be of higher quality and thus may be a more valuable form of human capital compared to high-school work experience. Presumably, higher quality work experience should be more conducive to job mobility, career development, and rising labor force attachment. Because the returns to human capital decrease over time, the value of experience acquired at later ages should depreciate less by adulthood compared to that acquired during early adolescence.

There is a great diversity in the school to work patterns that alter the timing of labor force entry (Ahituv et al. 1997). For example, women who pursue higher education delay full time labor force entry, on average, compared to women with no college, and therefore might attain less benefits from high school work. Moreover, there are compelling theoretical reasons to expect that periods of early unemployment, or employment instability, may actually benefit young women's long-term labor market prospects. Search theory posits that some "milling about" and job testing is necessary for young workers to optimize the match between their skills and available employment opportunities (Devine \& Keifer 1993; Topel \& Ward 1992). Search theory pertains to job switching specifically, but it is relevant to employment instability because job switching may involve jobless episodes between employers. Search theory also suggests that average turnover rates will decline over time because most "learning" takes place in initial job matches, with the benefits of subsequent transitions falling. Topel and Ward (1992) provide confirming empirical evidence, for young white men they report that during the first 10 years in the labor market a typical male worker holds seven jobs - two- 
thirds of his career total. Klerman and Karoly (1995) find that women hold fewer jobs than men, yet do not arrive at stable employment earlier. Moreover, they find substantial diversity among educational and race/ethnic sub-populations in the transition to stable employment.

Although some share of job turnover is useful to optimize "matches", even at the cost of lost work experience, too much instability can be counterproductive. An alternative view of the "shopping and thrashing" period is that early labor force instability may initiate a sorting process whereby some young women's experiences eventuate in early detachment from the world of work while others embark on a process of career development and strong market attachment. For example, among inner city youth, high levels of instability involving frequent episodes of joblessness often produce labor market discouragement and result in premature withdrawal from the labor market (Clark \& Summers 1979; Lynch 1989; Rees 1986). Thus, if labor force instability increases the probability of future joblessness by lowering stocks of accumulated work experience and allowing skills and human assets to decay, the long-term consequences of early labor force instability may include adult labor market detachment. Alternatively, if early instability largely involves refinement of the worker, job match and accommodation of educational attainment, then instability may augment adult market attachment.

The foregoing discussion of early work behavior highlights the importance of considering both the volatility and timing of work experience from a life course perspective for understanding the development of stable work careers. In other words, although many studies show that the amount of work experience accumulated is crucial for future employment prospects, other aspects of early work experiences also impact subsequent labor market outcomes. With regard to timing, we hypothesize that work experience accumulated at different stages of the early life course (high school, college, postschooling) will not have uniform effects on young women's labor market attachment. Human capital predicts that early experience should be less valuable than later experience because of decay, but it is also conceivable that the type of jobs held by enrolled teens do not provide the same returns as those held by adults (Hotz et.al. 1999). Specifically, we expect that work experience accumulated before the completion of formal education may be less beneficial than that acquired after schooling, especially secondary education, has ended. Moreover, we hypothesize that high school work experience will be inconsequential for women who postpone full-time labor market activity while attending college, and thereby acquiring general human capital, which is more relevant for future employment prospects. With regard to the volatility of labor force experience, we consider both age-specific unemployment experiences as well as the effects of repeated periods of unemployment - labor market instability over the early life course. We hypothesize that labor force instability during late adolescence is crucial for sorting young women into work profiles that represent varying degrees of labor market attachment. 


\section{Data}

We analyze 16 years of the National Longitudinal Survey of Youth (NLSY), a representative probability sample of 12,686 men and women aged 14 to 21 as of January 1, 1979, who were interviewed annually between 1979 and 1994. The detailed labor force histories provided by the NLSY make it ideal for studying labor force behavior. The NLSY work history file records labor force status on a weekly basis, which enables us to represent all intra- and interyear labor force transitions. This is important given our interest in labor force instability.

The NLSY Work History file includes 6,283 women. Because the retrospective information ${ }^{1}$ on labor force histories was less complete than the prospective data, we restrict the sample to women aged 13 to 16 in 1978 to reduce left-censoring of work careers (dropping 4,134 women). ${ }^{2}$ We also exclude the supplemental poor white sample $(n=262)$ and women who were not in the military oversample, but who had spent time in the military $(n=38)$ during the observation period. ${ }^{3}$ In addition, women lacking any labor force data for the entire period from age 16 to age 28 were dropped from the sample $(n=340)$ because our interest in labor market trajectories is irrelevant for them. An additional 97 women were dropped because of other missing data in their work history. Finally, because one measure of early labor force experience requires work activity status for the first two years following school leaving, we drop the 26 women who were in school the entire length of our observation period. These sample constraints produced an analysis sample of 1,386 young women. This number includes an oversamples of black and Hispanic youth provided by the NLSY to maximize sample sizes for tabular comparisons with white youth, but also because these samples are randomly drawn. ${ }^{4}$ We weighted all descriptive statistics using population weights available in the NLSY data file.

\section{Descriptive Analyses}

The descriptive analysis characterizes young women's labor force instability and identifies when instability declines and labor force stability increases during the early life course. This allows us to construct an informed indicator of stable careers for use in subsequent multivariate analyses. This analysis consists of two parts. First, we construct a three-category annual labor force experience variable for every age between 16 and 28. This variable is based on the number of weeks worked during a given age-year. For these annualized measures, we classify women as stably active if they were employed every week during a given age; unstably active if they both worked and experienced joblessness during an age-year (i.e., unemployed or out of the labor force); or stably inactive if they were jobless every week (see Clogg et al. 1990 and Hsueh \& Tienda 1995 for further justification of this classification scheme). Derived this way, unstable activity is a very heterogeneous category, including young women who spent most of the year working and women who 


\section{TABLE 1: Age Distribution of Activity Status and Number of Labor Force Transitions and Mean Weeks Worked among Unstably Active Women (Weighted)}

Labor Force Activity Status Unstable Activity: Transitions and Mean Weeks Worked

\begin{tabular}{|c|c|c|c|c|c|c|c|c|c|}
\hline \multirow[b]{2}{*}{ Age } & \multirow{2}{*}{$\begin{array}{c}\text { Stable } \\
\text { Inactivity }\end{array}$} & \multirow{2}{*}{$\begin{array}{l}\text { Unstable } \\
\text { Activity }\end{array}$} & \multirow{2}{*}{$\begin{array}{r}\text { Stable } \\
\text { Activity }\end{array}$} & \multicolumn{5}{|c|}{ Number of Transitions } & \multirow{2}{*}{$\begin{array}{r}\text { Mean } \\
\text { Weeks } \\
\text { Worked }\end{array}$} \\
\hline & & & & 1 & 2 & 3 & 4 & $5+$ & \\
\hline 16 & 33.3 & 57.1 & 9.6 & 35.5 & 31.4 & 16.0 & 10.0 & 7.2 & 24.3 \\
\hline 17 & 23.7 & 62.2 & 14.1 & 34.5 & 33.8 & 16.1 & 9.7 & 5.9 & 27.4 \\
\hline 18 & 20.0 & 62.9 & 17.0 & 25.5 & 37.1 & 13.7 & 11.8 & 11.8 & 27.7 \\
\hline 19 & 15.3 & 60.1 & 24.6 & 31.5 & 30.8 & 13.3 & 12.4 & 12.0 & 27.5 \\
\hline 20 & 14.4 & 56.6 & 29.0 & 33.0 & 34.2 & 13.4 & 12.6 & 6.9 & 30.2 \\
\hline 21 & 14.8 & 51.1 & 34.1 & 32.3 & 38.9 & 10.6 & 10.5 & 7.7 & 31.4 \\
\hline 22 & 14.2 & 47.3 & 38.5 & 41.5 & 36.4 & 9.3 & 7.1 & 5.6 & 32.8 \\
\hline 23 & 14.5 & 39.4 & 46.1 & 37.7 & 41.0 & 11.0 & 6.3 & 4.0 & 32.7 \\
\hline 24 & 14.2 & 35.6 & 50.2 & 38.3 & 41.8 & 7.5 & 8.7 & 3.8 & 33.2 \\
\hline 25 & 14.2 & 35.0 & 50.9 & 38.5 & 38.9 & 11.4 & 7.0 & 4.2 & 32.4 \\
\hline 26 & 15.1 & 34.3 & 50.7 & 37.9 & 39.0 & 12.2 & 6.4 & 4.5 & 33.8 \\
\hline 27 & 16.5 & 34.1 & 49.4 & 38.4 & 41.2 & 9.1 & 7.8 & 3.6 & 33.8 \\
\hline 28 & 18.0 & 31.9 & 50.1 & 39.9 & 35.3 & 12.1 & 8.0 & 4.6 & 33.4 \\
\hline
\end{tabular}

$(\mathrm{N}=1,386)$

spent most of the year without formal employment, as well as women who made multiple transitions between working and joblessness. Therefore, we also examine the number of labor force transitions and the number of weeks worked by unstably active women at each age. A labor force transition is defined as a change from employment to joblessness or from joblessness to employment (with joblessness subsuming women both unemployed and out of the labor force).

Table 1 , which presents age-specific activity state distributions, shows that the share of women stably employed rises with age, with visible spikes when key life cycle transitions typically occur, i.e., after high school graduation and again after college completion. These age-specific distributions do not indicate continuity in the experience states over time, but they do reveal aggregate temporal changes in young women's relative attachment to the labor market. The share of young women stably employed stabilizes at about age 24 , and thereafter hovers around $50 \%$. Concurrently, stable inactivity declines by about half over the 13-year age range, from a peak of $33 \%$ among 16-year-olds to under $15 \%$ after age 20 . The growing stability of women's labor force experiences is also evident in the decreasing shares 


\section{2 / Social Forces 79:3, March 2001}

classified as unstably active between ages 16-28. During their high school years, approximately $50 \%$ to $60 \%$ of young women experience at least one labor force transition during an age-year. This proportion drops to less than $50 \%$ at age 22 and to between $34 \%$ and $36 \%$ of all women after age 24 .

The middle and right panels of Table 1 provide further evidence of declining labor force instability as young women mature. Specifically, the frequency of annual labor force transitions among the unstably active declines with age, as indicated by the smaller shares with multiple annual labor force transitions. For example, at age 18 , when labor force instability peaks, approximately $37 \%$ of unstably active young women experienced three or more labor force transitions, but only $23 \%$ do so at age 22 . By age 24 , about $38 \%$ of unstably active women make only transition a year, compared to only $26 \%$ at age 18 .

The right-hand column of Table 1 presents the mean weeks worked at ages 1628 by unstably active women, which increase from a low of 24.3 weeks at age 16 to about 33 weeks at ages $24-28$. This pattern shows increasing commitment to the labor market. Not only does the share of unstably active women decrease, but this drop is accompanied by a change in the character of unstable activity itself. As women age, unstable activity more closely resembles stable activity, involving fewer annual transitions and more weeks worked. Thus, it appears that labor market attachment grows even for women who are unstably active in early adulthood.

While the age-specific distributions of labor force experience statuses presented above suggest some patterning in young women's labor market experiences, they do not reveal the emergence of employment continuity for individuals. To this end, Figure 1 graphs age-specific, within-state transition probabilities for two-year periods using the three-category experience variable defined above. Thus, each curve in Figure 1 represents the probability that a woman observed in a given labor force experience status at age $a$ remains in that state at age $a+1$. Although these agespecific transition probabilities are limited to two-year periods (i.e., are conditional on the experience state at the immediately preceding age only), they nonetheless yield important insights about state dependence and the emergence of labor force stability over the early life span.

Even at the youngest ages, the probability that a woman remains in the same state at age $a+1$ is highly dependent on her state at age $a$. For adolescence unstable activity at age $a$ is a good predictor of unstable activity at age $a+1$, but stable activity and stable inactivity are relatively poorer predictors of stable activity and stable inactivity, respectively, at the following age. However, the strength of state dependence for the three labor force statuses changes with age. As women mature, the continuity of unstable activity decreases while the continuity of both stable activity and stable inactivity rises, indicating a sorting of women who are increasingly attached and detached from the market, respectively. Pronounced changes in the direction and relative strength of inter-temporal status occur at the key life-course transitions - high school graduation and college completion. Between ages 18 and 22, the state dependence trend lines cross. By age 22, when the majority of 
FIGURE 1: Age-Specific, Within-State Transition Probabilities (Weighted)

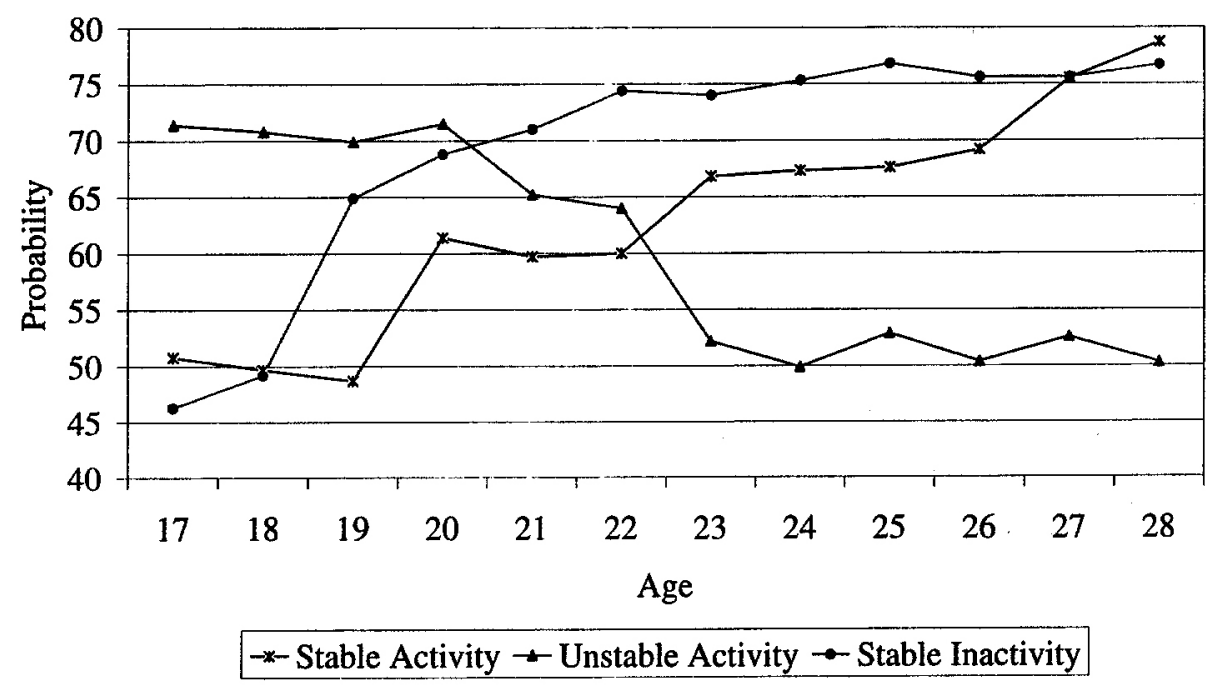

young women in our sample who attend college have graduated, state dependence in stable inactivity and stable activity peak, and the age continuity of unstable activity drops appreciably, as graduates transit from temporary, part time jobs to stable full-time employment (Donahoe \& Tienda 2000). By the end of our observation period, the probability of status continuity is approximately 77-79 percent for stably active and stably inactive women, but just over $50 \%$ for unstably active women.

Taken together, Table 1 and Figure 1 indicate that by age 25, young women's work careers have stabilized and reached an approximate equilibrium that continues through age 28 , the last age we observe all women. By age 25 , the percent of young women who are stably active for an age-year approaches $50 \%$, and remains at this level through age 28 . By age 28 , both the number of labor force transitions and the number of weeks worked by unstably active women also have stabilized. Also, by age 25, the vast majority of women who make transitions between work and non-work do so only one or two times per year and average half a year in the labor force. Because young women's labor force careers have stabilized by age 25 we scale labor force attachment by characterizing the continuity of employment between ages 25 and 28 as described below. 


\section{4 / Social Forces 79:3, March 2001}

\section{Conceptual Framework for Labor Force Attachment}

With little prior empirical foundation measuring women's labors force attachment we first developed a conceptual framework to represent a broad range of work activity profiles during young adulthood. We based our framework on Clogg's 3 annual labor force experience states (Clogg et al. 1990): stably active (SA); unstably active (UA) and stably inactive (SI) for each person-year between ages 25-28. Our use of the activity profiles to represent labor force attachment (LFA), assumes a hierarchical ordering wherein stable activity represents a higher level of attachment than unstable activity, which in turn indicates higher attachment than stable inactivity. All persons-years between ages 25 and 28 are weighted equally in the scaling, which means that a year of stable inactivity at ages 25 or 28 contributes equally to the level of LFA.

Table 2 depicts the conceptual framework used to derive the LFA scale. The highest level of LFA corresponds to women who were stably active for all four years (first category - 4SA). Women who were stably inactive the entire time between ages 25-28 exhibit the lowest level of attachment (last category - 4 SI). Between those two poles there are numerous activity profiles representing degrees of LFA. For example women in category 4 experienced two years of stable activity and two years of unstable activity (in any sequence). The ordering assumptions indicate a higher level of labor force attachment compared to women in category 6 , who spent two years in stable inactivity rather than unstable activity. In brief, the various rows within categories represent less time stably employed relative to time spent unstably employed, and less time both stably and unstably employed relative to stably inactive.

Table 2 also presents the distribution of women among the 15 attachment categories. The two modal "tail" categories, namely those consisting of either stable activity or stable inactivity for four consecutive years, represent $25 \%$ and $20 \%$ of all young adult women, respectively. The modal category of unstable activity (category 2) includes one year with at least one labor force transition and three years of stable activity, and accounts for $18 \%$ of the sampled women. ${ }^{5}$ Nearly 10 percent of mature women worked continuously for one full year and experienced at least one transition during each of the other three years (category 7), and an additional $10 \%$ of mature women had some employment activity for one year but were stably inactive during each of the other three years (category 14).

Because many categories have very few or no respondents, for analytical purposes we further collapse the 15 categories of young adult labor force activity into 5 mutually exclusive categories in descending order of attachment: (1) very high LFA: stably active for the past 4 years; (2) high LFA: stably active for 2-3 years; (3) moderate LFA: stably active one year; (4) low LFA: unstably active for 3-4 years (with zero years of stable activity), and very low LFA: stably inactive for 3-4 years (with no years of stable activity). In defining this scale, we first counted years of stable activity, and then for women with zero years of stable activity, we counted 
years of unstable activity. Finally we tallied years of stable inactivity using the principle that more years of SA indicate higher levels of LFA.

The last column of Table 2 summarizes the attachment scale yielded by this exercise. Over one in four women were stably active continuously between ages 25 and 28 and therefore exhibit the highest degree of attachment to the labor market. Approximately $20 \%$ of women were stably active 2-3 years in young adulthood, the second level of attachment. Nearly $15 \%$ of young adult women were either unstably active or stably inactive for 3 years between ages 25-28, but experienced one year of stable activity. Unstably active women who made at least one annual labor force transition between ages 25 and 28, but never worked a single year without interruption comprise $10 \%$ of the sample. Finally, stably inactive women who are least attached to the market included women who experienced at least 3 years of SI and not a single year of stable activity. This group represents about onein-three women years 25 to 28 .

Although interesting in its own right our purpose in designing a scale of labor force attachment is to assess how early work experiences are conducive to the establishment of stable work careers. Accordingly, we shift our focus to a multivariate analysis that allows a more precise assessment of whether and how prior market activity influences young women's labor force attachment. Specifically, we evaluate hypotheses about the timing and volatility of market experience as precursors to the establishment of stable work careers.

\section{Multivariate Analyses}

To examine the impact of early work experience on young women's labor force attachment, we estimate a series of multinomial logit models. Following Caspi et al. (1998) our analysis includes women's characteristics correlated with labor market behavior, such as race, Hispanic origin, family income and family structure when respondents' were 14, mothers completed education (in years), and whether the respondents' mothers worked in 1978-79. We also model young women's own educational attainment, AFQT score, work expectations at age 35 (ascertained in the 1979 and 1980 interviews), and work commitment at age 35, defined as desire to work even if not financially necessary at age 35 (ascertained in the 1979 interview). Family status variables include marital status at age 24, achieved fertility at age 24, and whether or not a birth was experienced between ages 25 and 28, the period over which we measure labor force attachment.

We measure early labor force experience in three ways to represent the quantity, timing, and volatility of time spent in the labor market before age 25 . To represent quantity, labor force experience accumulated by age 25 is measured as the number of months employed between ages 16 and $24 .{ }^{6}$ Second, to evaluate whether the 
TABLE 2: Typology of Women's Labor Force Attachment during Young Adulthood (Ages 25-28)

\section{Conceptual Framework}

\begin{tabular}{|c|c|c|c|c|c|c|c|}
\hline \multirow[b]{2}{*}{ Category } & \multicolumn{4}{|c|}{ Activity State in Each Age Year } & \multicolumn{2}{|l|}{ Experience } & Per- \\
\hline & 28 & 27 & 26 & 25 & Profile & $\mathrm{N}$ & cen \\
\hline \multicolumn{8}{|c|}{4 Years of Stable Activity } \\
\hline 1 & SA & SA & SA & SA & $4 \mathrm{SA}$ & 303 & 25.3 \\
\hline \multicolumn{8}{|c|}{$\begin{array}{c}\text { Any } 3 \text { Years of Stable Activity } \\
\text { (Any Sequence) }\end{array}$} \\
\hline 2 & SA & SA & SA & UA & $3(\mathrm{SA})+1(\mathrm{UA})$ & 248 & 18.4 \\
\hline & SA & SA & UA & SA & & & \\
\hline \multirow{6}{*}{3} & SA & UA & SA & SA & \multirow{6}{*}{$3(\mathrm{SA})+1(\mathrm{SI})$} & \multirow{6}{*}{1} & \multirow{6}{*}{0.03} \\
\hline & UA & SA & SA & SA & & & \\
\hline & SA & SA & SA & SI & & & \\
\hline & SA & SA & SI & SA & & & \\
\hline & SA & SI & SA & SA & & & \\
\hline & SI & SA & SA & SA & & & \\
\hline
\end{tabular}

Any 2 Years of Stable Activity

\begin{tabular}{|c|c|c|c|c|c|c|c|}
\hline \multirow[t]{6}{*}{4} & SA & SA & UA & UA & \multirow[t]{6}{*}{$2(\mathrm{SA})+2(\mathrm{UA})$} & \multirow[t]{6}{*}{0} & - \\
\hline & SA & UA & SA & UA & & & \\
\hline & SA & UA & UA & SA & & & \\
\hline & UA & SA & SA & UA & & & \\
\hline & UA & UA & SA & SA & & & \\
\hline & UA & SA & UA & SA & & & \\
\hline \multirow[t]{6}{*}{5} & SA & SA & UA/SI & SI/UA & \multirow{6}{*}{\multicolumn{2}{|c|}{$2(\mathrm{SA})+1(\mathrm{UA})+1(\mathrm{SI}) 20$}} & 1.8 \\
\hline & SA & UA/SI & SA & SI/UA & & & \\
\hline & SA & UA/SI & SI/UA & SA & & & \\
\hline & $\mathrm{UA} / \mathrm{SI}$ & SA & SA & SI/UA & & & \\
\hline & UA/SI & SI/UA & SA & SA & & & \\
\hline & $\mathrm{UA} / \mathrm{SI}$ & SA & SI/UA & SA & & & \\
\hline \multirow[t]{6}{*}{6} & SA & SA & SI & SI & $2(\mathrm{SA})+2(\mathrm{SI})$ & 0 & - \\
\hline & SA & SI & SA & SI & & & \\
\hline & SA & SI & SI & SA & & & \\
\hline & SI & SA & SA & SI & & & \\
\hline & SI & SI & SA & SA & & & \\
\hline & SI & SA & SI & $\mathrm{SA}$ & & & \\
\hline
\end{tabular}




\section{TABLE 2: Typology of Women's Labor Force Attachment during Young Adulthood (Ages 25-28) (Continued)}

\section{Conceptual Framework}

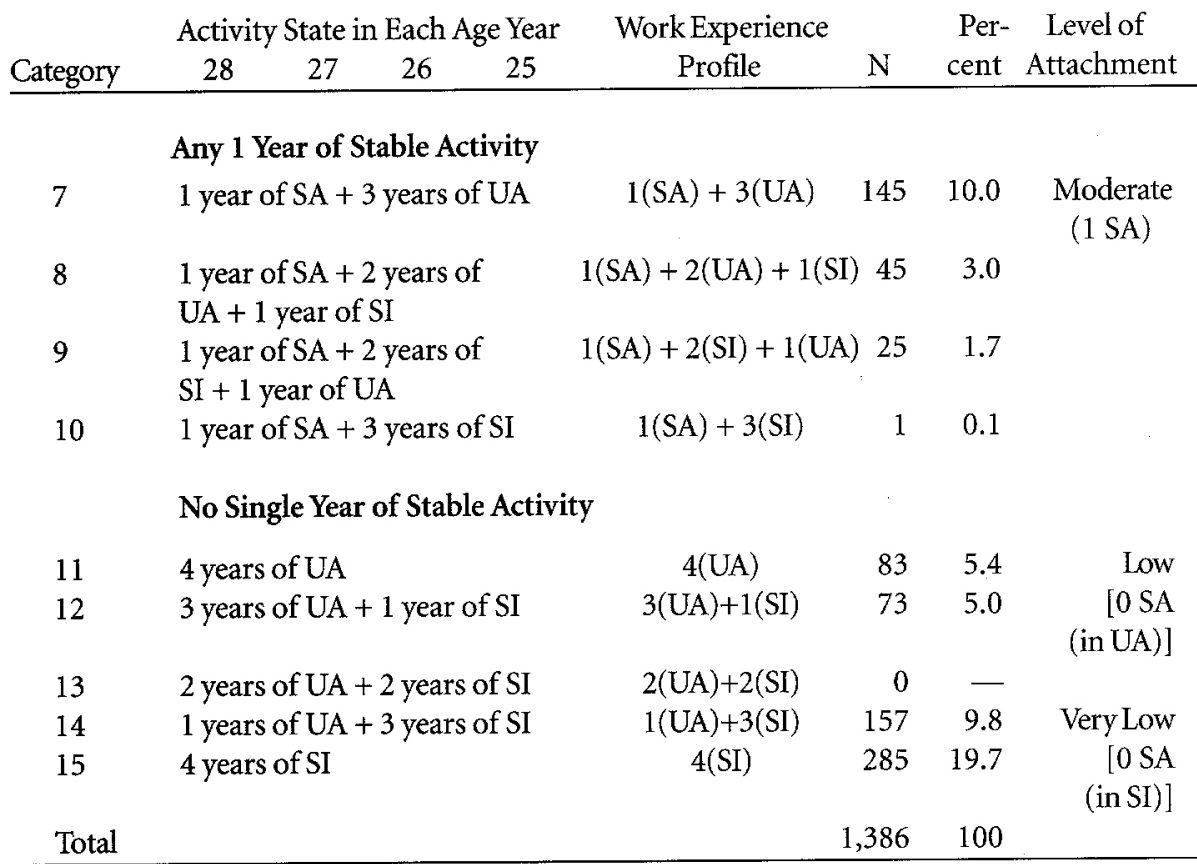

Note: $\mathrm{SA}=$ stably active; $\mathrm{UA}=$ unstably active; $\mathrm{SI}=$ stably inactive.

Assumptions: (1) LF attachment: SA > UA > SI; (2) Equal weights to all years between ages 25-28

effects of experience acquisition depend on its timing, we divide months worked into three segments: (1) experience accumulated during high school (or during the completion of high school equivalency classes); (2) experience accumulated during periods of college enrollment; (3) and experience acquired during periods of postschooling. Because women who prolong their schooling are making an explicit (and important) decision about human capital investment, we compare the "attachment" returns to experience for women who attended college and those who did not. We hypothesize that the labor force attachment of college attendants will be more sensitive to later experiences than to high school experience, and that attachment of women who made an early transition from school to work will be more sensitive to adolescent work experiences.

Third, to assess the volatility of early work experience on subsequent labor market attachment, we derive a measure of labor force instability, operationalized as the cumulative number of labor force transitions made before age $25 .^{7}$ Labor 


\section{8 / Social Forces 79:3, March 2001}

force transitions involve changes from joblessness (either unemployment or nonparticipation), to employment or vice versa. For example, the 249 weeks of labor force experience accumulated by age of 24 (the sample mean, of a possible 468 weeks) can be acquired in numerous ways. It can be attained in a single stretch, thus involving few labor force transitions, or as a series of short-lasting employment episodes, involving many labor force transitions. The transitions variable, therefore, captures how experience is acquired as distinct from the amount of experience accumulated. Based on prior research, we hypothesize that work experience acquired through unstable activity will be less conducive to establishing strong labor market attachment than experience acquired over protracted work episodes.

Model estimation is complicated because inclusion of births as an explanatory variable requires measures to deal with endogeneity. To obtain consistent estimates, we use a two-stage instrumental variable procedure that accounts for the simultaneity of the work and fertility decisions. Thus, we derive a predicted probability representing the propensity to experience a birth between ages 25 and 28 and use the predicted rather than the observed values in empirical estimates. As instruments in the prediction equation we use ideal family size as measured in 1979 , whether a child or an additional child is desired at age 24, Catholic religion, mother's education, respondent education, if respondent is married and the number of children born by age 24. The Appendix shows the first-stage birth model. Because of the two-stage procedure, the standard errors of the second stage multinomial logit equations may be biased. Thus, we use bootstrap procedures to estimate nonbiased standard errors for the structural equations. ${ }^{8}$

Table 3 reports descriptive statistics for all variables used in the multivariate models according to labor force attachment states. Hispanic women are slightly over-represented in very low and moderate levels of market attachment, but they are slightly under-represented among the high and the high, very high and low LFA levels. Black women are disproportionately represented among women with low levels of market attachment and under-represented among those with very high attachment levels. Background characteristics are also related to women's levels of LFA. Women from affluent families are more attached to the labor force, as are women reared by two parents. Women whose mothers were highly educated and who were in the work force were more attached to the market as young adults compared to women reared by less educated mothers and those who did not work outside the home. High school educated women are over-represented among women with the lowest levels of market attachment whereas the college-educated exhibit the strongest labor force attachment. Also, and consistent with a vast empirical literature based on cross-sectional data, married women are less attached to the market, as are women with children, compared to single and childless women. Those who were stably inactive for four consecutive years between ages 25 and 28 averaged 1.04 children at age 24 compared to 0.3 children for those stably employed all four years. 
As expected, women who accumulated fewer months of work experience by age 24 are less attached to the market in young adulthood. Those classified as having very low or low LFA averaged only 50 months of work experience up to age 24, where as moderately attached women accumulated 63 months of job experience. This means that women classified as moderately attached were in the market approximately half of all person months between ages 16 and 24. However women with high or very high LFA averaged 70 to 78 months of work experience, indicating they were in the market 65 to $72 \%$ of all months after age 15 . Disparities in the accumulation of labor force experience begin as early as high school, where more attached women at ages 25-28 also worked more during high school. For example, women with low and very low LFA accumulated about 10-12 months of high school work experience as compared to 18 months accumulated by women with very high LFA. This pattern, which suggests an early sorting into the work force, is also evident for college work experience and for post-school work experience. Women with low and very low LFA acquire about 35 months of post-school work experience as compared to about 48 months among highly attached women. The number of labor force transitions experienced by women are lowest among women with very high and very low levels of market attachment. This suggests that instability may operate differently in sorting women into stable and unstable market careers. Because levels of attachment based on early work profiles are systematically related to women's sociodemographic characteristics, assessing the influence of early work experience, and especially deciphering timing, volatility, and quantity effects, requires a multivariate analysis - to which we now turn.

\section{Results}

Table 4 reports multivariate results for three logistic regression models of laborforce attachment between ages 25 and 28. In all models the comparison group is 1 year of stable activity ( $1 S A) .^{9}$ Independent variables are grouped into six categories: race/ethnic status; family background; education and scholastic aptitude; marriage and childbearing; labor force aspirations; and labor force experience. ${ }^{10}$ Model 1 includes all covariates and a single measure of cumulative labor force experience. Model 2 breaks cumulative work experience into three segments: months worked while in high school, months worked while in higher education, and months worked while out of school. Model 3 adds the measure of cumulative labor force transitions. Models in Table 5 replicate model 3 for college goers and women who never attend college. In the interest of parsimony, Tables 4 and 5 present only the labor force experience covariates, and the effects of the other covariates (based on model 3) are depicted in Table 6.

Table 4 shows the coefficients of all labor force experience from all 3 models. Model 1 shows that each additional month of labor market experience prior to age 
TABLE 3: Weighted Means or Percents of Independent Variables, by Labor Force Attachment State

$\begin{array}{ccccll} & \text { Very } & & & & \text { Very } \\ & \text { Low } & \text { Low } & \text { Moderate } & \text { High } & \text { High } \\ \text { Total } & \text { LFA } & \text { LFA } & \text { LFA } & \text { LFA } & \text { LFA }\end{array}$

Raw percent

29.4

10.4

14.8

20.2

25.3

Race/ethnic

Hispanic

Black

White

(reference groups)

$\begin{array}{rrrrrr}6.7 & 7.8 & 6.3 & 8.5 & 6.0 & 5.0 \\ 14.8 & 16.9 & 20.7 & 14.1 & 14.0 & 10.9 \\ 78.5 & 75.3 & 72.9 & 77.4 & 80.0 & 84.0\end{array}$

Family background

Family income at age $14(\$ 1,000 \mathrm{~s})$ 23.5 19.6 20.6 18.8

26.1 29.1 Female-headed (18.3) (16.3)

(19.4)

(22.1)

household residence at

$$
\text { age } 14
$$

Mother's education

16.4

10.9

(3.6)

Mother worked in 1978-79

74.3
19.0

10.5

(3.8)

72.1
17.7

10.6

(3.4)

66.3
17.5

14.9

11.0

(3.7)

(3.6)

71.4

74.7
13.5

11.6

81.7

Education and scholastic

aptitude

\begin{tabular}{|c|c|c|c|c|c|c|}
\hline High-school dropout & 12.8 & 21.2 & 15.7 & 14.6 & 10.1 & 2.9 \\
\hline High-school graduate & 47.0 & 48.4 & 57.4 & 49.4 & 44.0 & 41.9 \\
\hline Some college & 20.6 & 17.7 & 16.7 & 17.6 & 21.5 & 26.6 \\
\hline College ( 4 years or more & e) 19.6 & 12.7 & 10.1 & 18.4 & 24.3 & 28.6 \\
\hline AFQT score & $\begin{array}{c}68.4 \\
(23.4)\end{array}$ & $\begin{array}{c}61.8 \\
(24.8)\end{array}$ & $\begin{array}{c}64.3 \\
(19.2)\end{array}$ & $\begin{array}{c}65.3 \\
(25.3)\end{array}$ & $\begin{array}{c}71.5 \\
(22.0)\end{array}$ & $\begin{array}{c}77.2 \\
(20.0)\end{array}$ \\
\hline
\end{tabular}

Marriage and childbearing

Married at age 24

47.8

Number of children

at age 24

0.71

Experience abirth,

0.39

(0.13)

ages 25-28

(0.13)

$54.1 \quad 46.8$

$1.04 \quad 1.06$

(1.11) (1.08)

0.40

0.39

(0.13)

$(0.13)$

53.2

46.1

39.0

0.66

0.57

0.34

$(0.86)$

$(0.87)$

0.40

0.39

0.37

(0.14)

(0.13)

(0.12) 
TABLE 3: Weighted Means or Percents of Independent Variables, by Labor Force Attachment State (Continued)

\begin{tabular}{|c|c|c|c|c|c|c|}
\hline & Total & $\begin{array}{l}\text { Very } \\
\text { Low } \\
\text { LFA }\end{array}$ & $\begin{array}{l}\text { Low } \\
\text { LFA }\end{array}$ & $\begin{array}{l}\text { Moderate } \\
\text { LFA }\end{array}$ & $\begin{array}{l}\text { High } \\
\text { LFA }\end{array}$ & $\begin{array}{l}\text { Very } \\
\text { High } \\
\text { LFA }\end{array}$ \\
\hline Raw percent & & 29.4 & 10.4 & 14.8 & 20.2 & 25.3 \\
\hline \multicolumn{7}{|l|}{ Labor force aspirations } \\
\hline $\begin{array}{l}\text { Work if income } \\
\text { unnecessary }\end{array}$ & 80.7 & 80.0 & 74.9 & 81.3 & 78.6 & 85.2 \\
\hline \multicolumn{7}{|c|}{$\begin{array}{l}\text { Labor force experience } \\
\text { prior to age } 24 \text { (months) }\end{array}$} \\
\hline $\begin{array}{l}\text { Cumulative } \\
\text { experience }\end{array}$ & $\begin{array}{c}63.6 \\
(28.2)\end{array}$ & $\begin{array}{c}52.0 \\
(32.0)\end{array}$ & $\begin{array}{l}49.6 \\
(24.9)\end{array}$ & $\begin{array}{c}62.7 \\
(25.8)\end{array}$ & $\begin{array}{l}70.4 \\
(22.6)\end{array}$ & $\begin{array}{c}78.1 \\
(20.9)\end{array}$ \\
\hline $\begin{array}{l}\text { High school } \\
\text { experience }\end{array}$ & $\begin{array}{c}13.6 \\
(11.7)\end{array}$ & $\begin{array}{c}11.5 \\
(11.1)\end{array}$ & $\begin{array}{c}9.9 \\
(11.0)\end{array}$ & $\begin{array}{c}12.4 \\
(11.5)\end{array}$ & $\begin{array}{l}14.3 \\
(11.2)\end{array}$ & $\begin{array}{c}17.7 \\
(11.8)\end{array}$ \\
\hline College experience & $\begin{array}{c}7.9 \\
(13.8)\end{array}$ & $\begin{array}{c}5.3 \\
(11.7)\end{array}$ & $\begin{array}{c}4.8 \\
(11.3)\end{array}$ & $\begin{array}{c}7.0 \\
(13.3)\end{array}$ & $\begin{array}{c}8.6 \\
(14.0)\end{array}$ & $\begin{array}{c}12.3 \\
(15.8)\end{array}$ \\
\hline $\begin{array}{l}\text { Postschool } \\
\text { experience }\end{array}$ & $\begin{array}{c}42.1 \\
(24.2)\end{array}$ & $\begin{array}{c}35.2 \\
(26.0)\end{array}$ & $\begin{array}{c}35.0 \\
(20.2)\end{array}$ & $\begin{array}{c}43.3 \\
(22.7)\end{array}$ & $\begin{array}{c}47.4 \\
(22.7)\end{array}$ & $\begin{array}{c}48.0 \\
(22.7)\end{array}$ \\
\hline $\begin{array}{l}\text { Cumulative } \\
\text { transitions }\end{array}$ & $\begin{array}{l}10.8 \\
(6.7)\end{array}$ & $\begin{array}{l}10.3 \\
(6.9)\end{array}$ & $\begin{array}{l}12.9 \\
(6.6)\end{array}$ & $\begin{array}{l}12.2 \\
(6.5)\end{array}$ & $\begin{array}{l}11.2 \\
(7.2)\end{array}$ & $\begin{array}{l}9.5 \\
(5.9)\end{array}$ \\
\hline $\mathrm{N}$ & 1,386 & 442 & 156 & 216 & 269 & 303 \\
\hline$(\mathrm{N}=1,386)$ & & & & & & \\
\hline
\end{tabular}

Note: Standard deviations are in parentheses.

24 increases the odds that women will be highly attached to the labor force by approximately $3 \%$, relative to being stably active for only one year between ages 25 to 28 . Correspondingly, each additional month of work experiences decrease the likelihood of women to be stably inactive or unstably active by 2 percent compared to the likelihood of being stably active for 1 year. These results are consistent with the predictions of human capital theory inasmuch as the higher stocks of work experience enhance future labor market prospects. These effects assume uniformity in the timing and manner in which work experience was acquired. 
TABLE 4: Odds Ratios of Prior Labor Force Experience on Categories of Labor Force Attachment

\section{Model 1}

\begin{tabular}{ccrc} 
Very Low & Low & High & VeryHigh \\
LFA & LFA & LFA & LFA \\
\hline
\end{tabular}

Labor force experience (months)

Cumulative experience

$\begin{array}{cccc}0.985^{* *} & 0.983^{* *} & 1.026^{* *} & 1.033^{* *} \\ (0.003) & (0.004) & (0.004) & (0.004)\end{array}$

High school experience

College experience

Postschool experience

Cumulative transitions
Model statistics
Log-likelihood
$-1832.541$
Pseudo R ${ }^{2}$
Number of observations
1,386

Model 2

\begin{tabular}{crrc} 
Very Low & Low & High & VeryHigh \\
LFA & LFA & LFA & LFA \\
\hline
\end{tabular}

Labor force experience (months)

Cumulative experience

High school experience

$\begin{array}{cccc}0.983^{*} & 0.964^{* *} & 0.997 & 1.014 \\ (0.009) & (0.012) & (0.010) & (0.009) \\ 1.010 & 0.998 & 1.040^{* *} & 1.037^{\star *} \\ (0.012) & (0.016) & (0.013) & (0.012) \\ 0.984^{* *} & 0.987^{\star} & 1.034^{* *} & 1.040^{\star *} \\ (0.004) & (0.005) & (0.005) & (0.005)\end{array}$

Cumulative transitions

College experience

Post-school experience

Log-likelihood

Pseudo ${ }^{2}$ 
TABLE 4: Odds Ratios of Prior Labor Force Experience on Categories of Labor Force Attachment (Continued)

\section{Model 3}

\begin{tabular}{cccc} 
Very Low & Low & High & VeryHigh \\
LFA & LFA & LFA & LFA \\
\hline
\end{tabular}

\section{Labor force experience (months)}

Cumulative experience

$\begin{array}{lcccc}\text { High school experience } & 0.984 \dagger & 0.957^{* *} & 0.998 & 1.016 \dagger \\ \text { College experience } & (0.009) & (0.012) & (0.010) & (0.009) \\ & 1.015 & 0.986 & 1.049^{* *} & 1.037^{* *} \\ \text { Postschool experience } & (0.012) & (0.017) & (0.013) & (0.012) \\ & 0.986^{* *} & 0.981^{* *} & 1.036^{* *} & 1.036^{* *} \\ \text { Cumulative transitions } & (0.004) & (0.006) & (0.006) & (0.005) \\ & 0.996^{*} & 1.073^{* *} & 0.995 & 0.917^{* *} \\ & (0.014) & (0.019) & (0.016) & (0.015)\end{array}$

Model statistics

Log-likelihood

$-1775.688$

Pseudo ${ }^{2}$

16.6

Number of observations

Note: Reference category $=$ moderate LFA. Asymptotic standard errors are in parentheses. Net of covariates reported in Table 6.

Source: NLSY Work History File, 1979-94

$\dagger \mathrm{p}<.10 \quad{ }^{*} \mathrm{p}<.05 \quad{ }^{* *} \mathrm{p}<.01$

Model 2 relaxes the assumption that labor force experience was accumulated in uniform ways across the life cycle by partitioning total experience into three components: months worked while in high school, months worked while in college (or other form or higher education); and months worked postschool enrollment. Consistent with our descriptive results, but somewhat inconsistent with predictions of human capital theory, these results indicate that high-school work experience does significantly influence women's labor force attachment between ages 25-28. In other words, the "attachment" returns to early work experience do not appear to deprecate for women with moderate levels of market attachment. Specifically, each additional month of high school employment decreases the likelihood of being in the lowest two attachment categories relative to experiencing 1 year of stable activity (the odds are $96 \%$ and $98 \%$, for the low LFA and very low LFA categories, respectively). College work experience differentiates women with moderate LFA 
TABLE 5: Odds Ratios of Prior Labor Force Experience on Categories of Labor Force Attachment for College Attendants and College Nonattendants

\begin{tabular}{|c|c|c|c|c|}
\hline & \multicolumn{4}{|c|}{ Model 3: High School Educated } \\
\hline & $\begin{array}{l}\text { Very Low } \\
\text { LFA }\end{array}$ & $\begin{array}{l}\text { Low } \\
\text { LFA }\end{array}$ & $\begin{array}{l}\text { High } \\
\text { LFA }\end{array}$ & $\begin{array}{l}\text { Very High } \\
\text { LFA }\end{array}$ \\
\hline \multicolumn{5}{|c|}{ Labor force experience (months) } \\
\hline High school experience & $\begin{array}{c}0.997 \\
(0.012)\end{array}$ & $\begin{array}{c}0.984 \\
(0.015)\end{array}$ & $\begin{array}{c}1.010 \\
(0.013)\end{array}$ & $\begin{array}{c}1.013 \\
(0.013)\end{array}$ \\
\hline \multicolumn{5}{|l|}{ College experience } \\
\hline Postschool experience & $\begin{array}{l}0.977^{* *} \\
(0.005)\end{array}$ & $\begin{array}{r}0.957^{*} \\
(0.007)\end{array}$ & $\begin{array}{l}1.015^{* *} \\
(0.006)\end{array}$ & $\begin{array}{l}1.029^{* *} \\
(0.007)\end{array}$ \\
\hline Cumulative transitions & $\begin{array}{l}0.955^{\star} \\
(0.019)\end{array}$ & $\begin{array}{l}1.100^{* *} \\
(0.027)\end{array}$ & $\begin{array}{c}0.995 \\
(0.021)\end{array}$ & $\begin{array}{l}0.929^{* *} \\
(0.024)\end{array}$ \\
\hline $\begin{array}{l}\text { Model statistics } \\
\text { Log-likelihood } \\
\text { Pseudo } \mathrm{R}^{2} \\
\text { Number of observations }\end{array}$ & $\begin{array}{r}-1114.968 \\
17.4 \\
882\end{array}$ & & & \\
\hline & \multicolumn{4}{|c|}{ Model 3: College Educated } \\
\hline & $\begin{array}{l}\text { Very Low } \\
\text { LFA }\end{array}$ & $\begin{array}{l}\text { Low } \\
\text { LFA }\end{array}$ & $\begin{array}{l}\text { High } \\
\text { LFA }\end{array}$ & $\begin{array}{l}\text { VeryHigh } \\
\text { LFA }\end{array}$ \\
\hline \multicolumn{5}{|c|}{$\begin{array}{l}\text { Labor force experience (months) } \\
\text { Cumulative experience }\end{array}$} \\
\hline High school experience & $\begin{array}{r}1.019 \\
(0.015)\end{array}$ & $\begin{array}{r}1.018 \\
(0.028)\end{array}$ & $\begin{array}{r}1.012 \\
(0.015)\end{array}$ & $\begin{array}{r}1.010 \\
(0.015)\end{array}$ \\
\hline College experience & $\begin{array}{l}0.975 \dagger \\
(0.013)\end{array}$ & $\begin{array}{r}0.970 \\
(0.019)\end{array}$ & $\begin{array}{r}1.000 \\
(0.019)\end{array}$ & $\begin{array}{r}0.987 \\
(0.018)\end{array}$ \\
\hline Postschool experience & $\begin{array}{r}0.989 \\
(0.010)\end{array}$ & $\begin{array}{c}0.933^{\star} \\
(0.020)\end{array}$ & $\begin{array}{r}1.016 \\
(0.011)\end{array}$ & $\begin{array}{c}1.022^{*} \\
(0.011)\end{array}$ \\
\hline Cumulative transitions & $\begin{array}{r}1.008 \\
(0.025)\end{array}$ & $\begin{array}{r}1.010 \\
(0.041)\end{array}$ & $\begin{array}{r}0.994 \\
(0.023)\end{array}$ & $\begin{array}{c}0.925^{* *} \\
(0.229)\end{array}$ \\
\hline \multicolumn{5}{|l|}{ Model statistics } \\
\hline Log-likelihood & 646.301 & & & \\
\hline Pseudo $\mathrm{R}^{2}$ & 15.9 & & & \\
\hline Number of observations & 504 & & & \\
\hline
\end{tabular}

Note: Reference Category = Moderate LFA. Asymptotic standard errors are in parentheses. Net of covariates similar to those reported in Table 6.

Source: NLSY Work History File, 1979-94

$\dagger \mathrm{p}<.10 * \mathrm{p}<.05 \quad * * \mathrm{p}<.01$ 
from those with 2 or more years of stable activity. Each additional month of work experience while enrolled in college increases the odds of being highly or very highly attached to the market by approximately 4 percent relative to a moderate level of attachment (i.e., having only one year of stable activity). A broad generalization is that high school work experience helps to sort women among the lower levels of LFA whereas college work experience differentiates women among the higher levels of LFA. Post-school work experience is a substantial predictor of women's market attachment after age 24 . Each additional month of experience accumulated outof-school significantly decreases women's chances of being less attached to the market then moderate LFA and increases her chances of being more highly attached to the labor market after age 24 .

This pattern persists in model 3 which considers the volatility of labor force experience based on a measure of cumulative labor force transitions before age 25 . To some degree, instability perpetuates itself inasmuch a greater number labor force transitions prior to age 25 lowers the probability of being stably employed between ages 25-28. Each labor force transition experienced before age 25 lowers women's odds of being very highly attached to the labor market by $8 \%$ relative to moderately attached women, but there are no differences between moderate and high attachment. Probably this reflects the heterogeneous character of the moderate attachment category, and the similar number of average transitions achieved by both groups. At the other end of the attachment spectrum, frequent transitions are also less likely to eventuate very low LFA (stable inactivity), but instability is more likely to result in low LFA (unstable activity). Each labor force transition before age 25 increases women's odds of low labor force attachment by $7 \%$ relative to the odds of moderate attachment. This lends support to our hypothesis that work experience acquired through unstable activity is less conducive to strong labor market attachment than experience acquired over protracted work episodes.

Because women's diverse pathways from school to work directly influence their work activity over the life course, we reestimate model 3 separately for high school and college-educated women (Table 5). This specification considers how the amount, the timing and the volatility of labor force experience influences adult labor market attachment. Results based on education-specific groups show that early instability is more consequential for women who did not pursue college education. For high-school educated women, each additional labor force transition before age 25 lowers the odds of being in the very high LFA category relative to moderate LFA by $7 \%$, on average, and it increases the odds of low attachment. For college-educated women, instability differentiates between moderate and very high LFA, but not among the other statuses once the amount and timing of experience acquisition is taken into account. This is reasonable because labor force instability of college-educated women is not only related to their protracted educational investment process, which often permits employment only over sporadic periods, but also because both school and work activities of these women are geared to the 
TABLE 6: Multinomial Logit Estimates of Background Characteristics on Categories of Labor-Force Attachment

Model 3

\begin{tabular}{crcc} 
VeryLow & Low & High & VeryHigh \\
LFA & LFA & LFA & LFA \\
\hline
\end{tabular}

Racelethnic

$\begin{array}{lrrrr}\text { Hispanic } & 0.792 & 0.729 & 0.890 & 0.604^{+} \\ & (0.192) & (0.232) & (0.250) & (0.169) \\ \text { Black } & 0.589^{*} & 1.180 & 1.550 & 1.428 \\ & (0.150) & (0.038) & (0.439) & (0.403)\end{array}$

Family background

$\begin{array}{lrrrr}\text { Family income } & 1.000 & 1.008 & 1.008 & 1.024^{* *} \\ & (0.006) & (0.008) & (0.007) & (0.066) \\ \text { Female headed household } & 1.121 & 0.847 & 0.934 & 0.867 \\ & (0.246) & (0.242) & (0.237) & (0.224) \\ \text { Mother's education } & 0.979 & 0.990 & 0.967 & 0.928^{* *} \\ & (0.026) & (0.034) & (0.030) & (0.028) \\ \text { Mother worked } & 0.850 & 0.502^{* *} & 0.674 \dagger & 1.171\end{array}$

Education and scholastic aptitude

\begin{tabular}{lrrrr} 
High school dropout & 0.848 & 0.630 & $0.535^{\star}$ & $0.486^{*}$ \\
& $(0.211)$ & $(0.201)$ & $(0.180)$ & $(0.177)$ \\
Some college & $0.496^{* *}$ & $0.520 \dagger$ & 0.756 & 0.794 \\
& $(0.130)$ & $(0.177)$ & $(0.216)$ & $(0.217)$ \\
College (4 years or more) & $0.296^{* *}$ & $0.900^{* *}$ & 1.227 & 1.735 \\
& $(0.128)$ & $(0.057)$ & $(0.554)$ & $(0.747)$ \\
AFQT score & 0.997 & $1.017^{*}$ & 0.992 & $1.010 \dagger$ \\
& $(0.005)$ & $(0.007)$ & $(0.006)$ & $(0.006)$ \\
\hline
\end{tabular}

establishment of stable work careers. In addition these results show that the LFA of both college and high school-educated women is more responsive to post-school work activity than to experience acquired while enrolled in school. In other words, after accounting for school-to-work pathways, the effect of early employment experience is diminished, suggesting that educational attainment mediates the effect of early work experience on subsequent labor force attachment (Hotz et al., 1999). ${ }^{11}$

The descriptive results suggested that mature labor force attachment has roots in women's background and demographic characteristics. The point estimates presented in table 6 (coefficients for all background covariates derived from 
TABLE 6: Multinomial Logit Estimates of Background Characteristics on Categories of Labor-Force Attachment (Continued)

Model 3

\begin{tabular}{cccc}
$\begin{array}{c}\text { Very Low } \\
\text { LFA }\end{array}$ & Low & High & VeryHigh \\
& LFA & LFA & LFA \\
\hline
\end{tabular}

Marriage and childbearing

Married

Birth in ages 25-28 (predicted prob.) 0.200

Labor force aspirations

$\begin{array}{lrrrr}\text { Expect to be working at age 35 } & 0.541 \dagger & 0.449^{*} & 1.298 & 1.351 \\ & (0.179) & (0.176) & (0.516) & (0.524) \\ \text { Work if income not needed } & 0.643 \dagger & 0.975 & 0.547^{*} & 0.922 \\ & (0.148) & (0.290) & (0.142) & (0.253)\end{array}$

Model statistics

Log-likelihood

$-1775.688$

Pseudo $\mathrm{R}^{2}$

16.6

Number of observations

Notes: Reference category is moderate LFA. The asymptotic standard errors are in parentheses. Standard errors are bootstrap estimates from 1,000 replications. Models include missing flags for AFQT, mothers education, and family income. Net of covariates reported in Table 4 .

$\dagger \mathrm{p}<.10 \quad * \mathrm{p}<.05 \quad * * \mathrm{p}<.01$

model 3, Table 4) ${ }^{12}$ indicate that black women's odds of very low LFA relative to moderate LFA (net of labor force experience) are $60 \%$ of those of comparable white women. Further analysis reveals that black women are less likely than whites to have very low LFA, compared to all other states. ${ }^{13}$ Thus, controlling for experience and background variables, black women have higher labor force attachment than comparable white women. However, Hispanic and white women are equally likely to be attached to the labor market, other things equal. Women's family background also influences their labor force attachment but not uniformly among levels of LFA.

Educational attainment and scholastic aptitude are important predicators of young women's labor force attachment in the expected direction. High school dropouts have greatly decreased odds of being stably employed between ages 25-28 relative to women who graduated from high school. Specifically, the odds of a High School dropout being very highly attached to the market relative to moderately 


\section{8 / Social Forces 79:3, March 2001}

attached are only half the odds of high school graduates. College education is also strongly associated with higher levels of labor force attachment and it lowers the odds of very weak LFA relative to moderate LFA by 70 percent. Not surprisingly, experiencing a birth between ages 25 and 28 undermines labor force attachment.

\section{Discussion}

Our investigation of labor force attachment hypothesized (1) that the accumulation of early work experience influences the establishment of adult market careers (amount of work experience); (2) that the life-course stage at which work experience is accumulated shapes its impact on subsequent outcomes (timing of work experience); and (3) that labor force instability sorts young women into work profiles representing varying degrees of labor market attachment (volatility of work experience). On balance, the empirical results lend support to each of these premises, although some qualifications are warranted.

Results show that early experience influences young women's labor force attachment between ages 25-28. We also show that all three aspects of early experience acquisition, the amount, the timing, and the volatility, shape young adult women's labor market attachment. Our analyses demonstrate that the more work experience accumulated during the early adult period, the higher the likelihood of very high labor force attachment between ages $25-28$. This result will not surprise labor economists. While labor force experience accumulated after the end of schooling promotes subsequent labor force attachment and has the most substantial effect on the establishment of stable work career, market experience accumulated while enrolled in high school and while enrolled in college are also conducive to labor market attachment of adult women. High school work experience mainly promotes a minimal attachment to the market, but does not elevate women's prospects of becoming highly attached. The opposite obtains for college work experience, which largely enhances high levels of attachment.

In addition, we demonstrate the significance of the volatility of labor market experience for the establishment of stable work careers. Early labor force instability among young women is an important precursor of weaker labor force attachment at ages 25-28. As opposed to job mobility that might leads to optimal job matching, labor force instability weakens young women's labor market attachment. Thus, the manner in which work experience is accumulated is important above and beyond the extent of that experience. Gwartney-Gibbs (1988) suggests that intermittency negatively affects future employment prospects because it signals unreliability to potential employers who consider women with spotty resumes risky job candidates. In addition, early instability may limit a young woman's ability to progress beyond jobs that are themselves unstable (e.g., those sensitive to economic downturns). 
Indeed, Alon and Tienda (2000) demonstrate the long lasting negative effect of labor force transitions on young woman's wage prospects.

These results also suggest that the influences of early work experiences on subsequent labor force outcomes is driven both by causal and sorting processes. We propose this conclusion because the effects of early work experience on adult LFA are diminished after we stratify the sample for school-to-work pathways. In other words, the differences in labor force attachment after age 24 probably reflect pre-existing differences that sort women into different human capital investment profiles rather than real returns from early work experiences (Hotz et al. 1999). Further confirmation of this hypothesis requires modeling unobserved heterogeneity using dynamic specifications, which are beyond the scope of our objectives.

We believe that the empirical results have important policy implications. Understanding the roots of stable labor force attachment and the inequality produced by unstable attachment is crucial for the design of programs aimed at reducing negative youth outcomes. Advocates of school-to-work programs argue that these interventions - vocational and cooperative education, career academies, and tech-prep and apprenticeship programs - decrease the odds of early unemployment by improving educational quality, motivating students, providing job skills, and connecting students to the world of work. Though hard evidence that school-to-work programs decrease early youth unemployment is limited (see Donahoe \& Tienda 2000 for a review), our results invite further investigation of the benefits of these programs. Specifically, our results point to long-term benefits - the establishment of stable work careers - for any program that provides the short-term benefit of avoiding joblessness during high school. However, this outcome appears to depend on the amount of education acquired. Because our empirical results reveal significant LFA returns to educational attainment, we join others who advocate that the amount of time devoted to the labor market while enrolled in school should be kept to levels that do not undermine educational pursuits (Hotz et al. 1999; Hotz \& Tienda 1998; Tienda \& Ahituv 1996). 
Mother's education

$-.158$

(.124)

Catholic

Education (years)

Married

Number of children

Ideal family size

Desires another child

Log-likelihood

873.885

Number of observations 1,386

Note: Asymptotic standard errors

$* * \mathrm{p}<.05$

\section{Notes}

1. That was obtained from respondents who were 17-20 years old in 1978 .

2. This decision also drops the oversample of youth who were enlisted in the military as of 1979. All women in the military oversample were born before January 1, 1962. Dropping this oversample is reasonable also because these women were only followed until 1984 and then dropped from the study. This subjects these observations to both right and left censoring.

3. Women in military service often experience different employment and occupational profiles compared to their civilian counterparts and their inclusion requires separate models (Waite \& Berryman, 1986).

4. The inclusion of minority oversamples does not distort statistical inferences because they are statistically similar to the random sample.

5. It is conceivable that all four years involve one labor force transition because interview dates varied over time and the precision of transitions may be affected. 
6. We use a very precise measures of work experience, which are constructed based on the number of week in employment, and than transformed it into months of experience to ease interpretation.

7. We tested whether the relationship between number of labor force transitions and labor force attachment was nonlinear with a squared term. This variable was not significant.

8. Bootstrapping provides a way of obtaining measures of statistical accuracy when no other formulas are available or are cumbersome. The accuracy of bootstrap estimates

9. We believe that this is the best reference group of labor force attachment because it permits us to discern both positive and negative varience in attachment.

10. Flags for missing values are included in all models but are not reported in results presented here. These flags capture any bias introduced by the non-random distribution of missing values, thus purging substantively important coefficients of potential bias. Flags are not significant in any model.

11. See Hotz et al. for comparable insights about young men's wage determination.

12. We also fit a model that includes all covariates except labor force experience measures (base model). Results are available upon request.

13. Multinomial logit analysis with different comparison groups.

\section{References}

Ahituv, Avner, Marta Tienda, and V. Joseph Hotz. 1997. "Pathways from School to Work among Black, Hispanic and White Young Men in the 1980s." Unpublished manuscript, Princeton University.

Ahituv, Avner, Marta Tienda, and Angela Tsay. 1998. "Early Employment Activity and School Continuation Decisions of Young White, Black and Hispanic Women." Unpublished manuscript, Princeton University.

Alon, Sigal, and Marta Tienda. "Employment and Wage Consequences of Young Women's Labor Force and Job Transitions." Office of Population Research. Working Paper No. 2000-1. May, 2000.

Baruch, Grace K., Lois Biener, and Rosalind C. Barnett. 1987. "Women and Gender in Research on Work and Family Stress." American Psychologist 42:130-36.

Becker, Brian E., and Stephen M. Hills. 1980. "Teenage Unemployment: Some Evidence of the Long-Run Effects on Wages." Journal of Human Resources 15:354-72.

- 1983. "The Long-Run Effects of Job Changes and Unemployment among Male Teenagers." Journal of Human Resources 17:197-211.

Blair, Sampson and Daniel Lichter. 1991. "Measuring the Division of Household Labor: Gender Segregation of Housework among American Couples." Journal of Family Issues 12:91-113.

Blau, Francine, Marianne Ferber, and Anne Winkler. 1998. The Economics of Women, Men, and Work. Prentice Hall. 


\section{2 / Social Forces 79:3, March 2001}

Carr, Rhoda Viellion, James D. Wright, and Charles J. Brody. 1996. "Effects of High School Work Experience a Decade Later: Evidence from the National Longitudinal Survey." Sociology of Education 69:66-81.

Caspi, Avshalom, Bradley R. Wright, Terrie E. Moffitt, and Phil A. Silva. 1998. "Early Failure in the Labor Market: Childhood and Adolescent Predictors of Unemployment in the Transition to Adulthood." American Sociological Review 63:424-51.

Chaplin, Duncan and Jane Hannaway. 1996. High School Employment: Meaningful Connections for At-Risk Youth. Washington, D.C.: The Urban Institute.

Clark, Kim B., and Lawrence H. Summers. 1979. "Labor-Market Dynamics and UnemploymentReconsideration." Brookings Papers on Economic Activity 1:13-72.

. 1982. "Labour Force Participation: Timing and Persistence." Review of Economic Studies 49: 825-44.

Clogg, Clifford, Scott Eliason, and Robert Wahl. 1990. "Labor-Market Experiences and LaborMarket Outcomes." American Journal of Sociology 95:1536-76.

Coleman, James. 1984. "The Transition from School to Work." Research in Stratification and Mobility 3:27-59.

Devine, Theresa, and Nicholas Kiefer. 1993. “The Empirical Status of Job Search Theory." Labour Economics 1:3-24.

Donahoe, Debra and Marta Tienda. 2000. "Human Asset Development and the Transition from School to Work: Policy Lessons for the Twenty-first Century." Office of Population Research. Working Paper No. 98-3. Princeton University.

- 1999. "The Transition from School to Work: Is there a Crisis and What Can Be Done?" in Securing the Future: Investing in Children from Birth to College, edited by Sheldon Danzinger and Jane Waldfogel. Russel Sage Foundation.

Efron, Bradley. 1990. "More Efficient Bootstrap Computations." Journal of the American Statistical Association, 85: 79-89.

Elliott, Marta, and Toby Parcel. 1996. "The Determinants of Young Women's Wages: Comparing the Effects of Individual and Occupational Labor Market Characteristics." Social Science Research 25:240-59.

Ellwood, David. 1982. “Teenage Unemployment: Permanent Scars or Temporary Blemishes.” Pp. 349-85 in . The Youth Labor Market Problem: Its Nature, Causes and Consequences, edited by W.B. Freeman and David A. Wise. University of Chicago Press.

Entwisle, Doris R., Karl L. Alexander, and Linda Steffel Olson. 2000. "Early Work Histories of American Youth." American Sociological Review 65:279-97.

Gottshalk, Peter and Robert Moffitt. 1994. "The Growth of Earnings Instability in the U.S. Labor Market." Brookings Papers on Economic Activity 2:217-72.

Gwartney-Gibbs, Patricia. 1988. “Women's Work Experience and the 'Rusty Stills' Hypothesis: A Reconceptualization and Reevaluation of the Evidence." Women and Work 3:169-87.

Hakim, Catherine. 1991. "Grateful Slaves and Self-Made Women: Fact and Fantasy in Women's Work Orientations." European Sociological Review 7:101-21.

Hill, M. Anne, and June O'Neill. 1992. "Intercohort Change in Women's Labor Market Status." Research in Labor Economics 13:215-86. 
Hotz, Joseph, and Marta Tienda. 2001. "Education and Employment in a Diverse Society: Generating Inequality through School-to-Work." In American Diversity: A Demographic Challenge for the Twenty-First Century, edited by Nancy Denton and Stuart Tolnay. SUNY Press. In press.

Hotz, Joseph, Linxin Xiu, Marta Tienda, and Avner Ahituv. 1999. "Are There Returns to the Wages of Young Men from Working While in School?" National Bureau of Economic Research. Working Paper Series. Working Paper no. 7289. August 1999.

Hsueh, Sheri, and Marta Tienda. 1996. "Gender, Ethnicity, and Labor Force Instability." Social Science Research 25:73-94.

1995. "Earnings Consequences of Employment Instability among Minority Men." Research in Social Stratification and Mobility 14:39-69.

Keane, Michael, and Kenneth Wolpin. 1997. "The Career Decisions of Young Men." Journal of Political Economy 105:473-522.

Klerman, Jacob A., and Lynn A. Karoly. 1995. "The Transition to Stable Employment: The Experience of U.S. Youth in Their Early Labor Market Career." Berkeley, Calif.: National Center for Research in Vocational Education, University of California, Berkeley.

Light, Audrey, and Ureta, Manuelita. 1995. "Early-Career Work Experience and Gender Wage Differentials." Journal of Labor Economics 13:121-54.

Lynch, Lisa M. 1989. “The Youth Labor Market in the Eighties: Determinants of Re-employment Probabilities for Young Men and Women." The Review of Economics and Statistics 71:3745.

Meyer, Robert H., and David A. Wise. 1982. "High School Preparation and Early Labor Force Experience." Pp. 277-347 in The Youth Labor Market Problem: Its Nature, Causes and Consequences, edited by W.B. Freeman and David A. Wise. University of Chicago Press.

Moen, Phyllis, and Ken R. Smith. 1986. "Women at Work: Commitment and Behavior over the Life Course." Sociological Forum 1:450-75.

Mortimer, Jeylan, and Michael Finch. 1992. "Work Experience in Adolescence." Paper Commissioned for Public/Private Ventures, Philadelphia, Penn.

Rees, Albert. 1986. "An Essay on Youth Joblessness." Journal of Economic Literature 24:613-28.

Rich, Lauren. 1996. "The Long-Run Impact of Teenage Work Experience: A Reexamination." Review of Black Political Economy 25:11-36.

Robinson, John P. 1988. "Who's Doing the Housework?" American Demographics 10:24-28.

Rosenfeld, Rachel. 1996. "Women's Work Histories." Pp. 199-222 in Fertility in the United States: New Patterns, New Theories, edited by John Casterline, Ronald Lee, and Karen Foote. Supplement to Population and Development Review, vol. 22. New York: The Population Council.

Ruhm, Christopher J. 1995. “The Extent and Consequences of High School Employment." Journal of Labor Research 16:293-303.

Steinberg, Laurence D., Ellen Greenberger, Maryann Jacobi, and Laurie Garduque. 1981. “Early Work Experience: A Partial Antidote for Adolescent Egocentrism." Journal of Youth and Adolescence 10:141-57.

Stephenson, Stanley. 1982. "A Markov Model of School versus Work Choices of Black and White Young Men." Applied Economics 14:43-61. 


\section{4 / Social Forces 79:3, March 2001}

Tienda, Marta and Avner Ahituv. 1996. "Ethnic Differences in School Departure: Does Youth Employment Promote or Undermine Educational Achievement?" Pp. 93-110 in Of Heart and Mind: Social Policy Essays in Honor of Sar Levitan, edited by Garth Mangum and Stephen Mangum. Kalamazoo, Michigan: Upjohn Institute.

Topel, Robert H., and Michael P. Ward. 1992. "Job Mobility and the Careers of Young Men." Quarterly Journal of Economics 107:439-79.

Waite, Linda J., and Sue E. Berryman. 1986. "Job Stability among Young Women - A Comparison of Traditional and Nontraditional Occupations.” American Journal of Sociology 92:568-95.

Wenk, DeeAnn, and Rachel Rosenfeld. 1992. "Women's Employment Exit and Reentry: JobLeaving Reasons and their Consequences." Research in Social Stratification and Mobility 11: 127-50. 